\title{
Analisis Kemampuan Pemecahan Masalah Siswa SMP Ditinjau dari Kemampuan Memahami, Merencana, dan Menyelesaikan Masalah
}

\author{
Sujinal Arifin ${ }^{1 *}$, Zulkardi ${ }^{2}$, Ratu ilma Indra Putri ${ }^{3}$, Yusuf Hartono ${ }^{4}$ \\ ${ }^{1}$ UIN Raden Fatah, Palembang, Sumatera Selatan 30126, Indonesia \\ ${ }^{2,3,4}$ Universitas Sriwijaya, Palembang, Sumatera Selatan 30139, Indonesia \\ Pengiriman: 07/Februari/2021; Diterima: 25/Maret/2021; Publikasi: 31/Maret/2021 \\ DOI: https://doi.org/10.31629/jg.v6i1.3050
}

\begin{abstract}
Abstrak
Tujuan penelitian ini adalah untuk menganalisis tentang kemampuan pemecahan masalah tipe word problems beserta factor penyebabnya. Penelitian ini menggunakan subjek siswa SMP Negeri 3 Palembang dengan jumlah siswa 19 orang. Penelitan ini merupakan penelitian deskriptif. Pengumpulan data dilakukan dengan menggunakan teknik tes dan angket. Semua data yang diperoleh secara umum dianalisis secara deskriptif kuantitatif dan kualitatif. Data kuantitatif disajikan dalam bentuk diagram batang, sedangkan data dalam bentuk kualitatif disajikan dengan cara dinarasikan. Dari hasil analisis data diperoleh informasi bahwa mayoritas siswa memahami masalah. Akan tetapi hanya beberapa siswa yang dapat menyelesaikan masalah dengan benar. Banyak siswa yang tidak membuat perencanaan dalam menyelesaikan masalah padahal perencanaan dapat digunakan sebagai jembatan dalam penggunaan informasi dan pengetahuan yang telah mereka miliki sebelumnya untuk menyelesaikan masalah. Dari hasil angket diperoleh kesimpulan bahwa ada beberapa faktor penting yang mempengaruhi keberhasilan siswa dalam menyelesaikan masalah, diantaranya adalah kemampuan dalam mengingat konsep dan teorema dalam penyelesaian masalah, suka atau tidak pada matematika, frekuensi seberapa sering latihan matematika, atau pengalaman seperti pernah menyelesaikan masalah yang sama.
\end{abstract}

Kata kunci: analisis; pemecahan masalah; memahami; merencana; solusi

\begin{abstract}
The purpose of this study was to analyze the problem-solving skills of the type of word problems and their causes. This study used the subject of students of SMP Negeri 3 Palembang with a total of 19 students. This research is a descriptive study. Data collection was carried out using test and questionnaire techniques. All the data obtained were generally analyzed descriptively quantitatively and qualitatively. Quantitative data is presented in the form of a bar chart, while data in qualitative form is presented in narrative form. From the results of data analysis, it was found that many students understood the problem. However, only a few students can solve the problem correctly. Many students do not make plans to solve problems even though planning can be used as a bridge in using the information and knowledge they already must solve problems. From the results of the questionnaire, it was concluded that there were several important factors that influenced the success of students in solving problems, including the ability to remember concepts and theorems in problem solving, like it or not in mathematics, the frequency of how often mathematics exercises, or experiences such as having solved the same problem.
\end{abstract}

Keywords: analysis; problem-solving; understanding; planning; solution 


\section{JURNAL GANTANG. Maret 2021; VI(1): 29 - 38 \\ p-ISSN. 2503-0671 \\ e-ISSN. 2548-5547}

\section{Pendahuluan}

Hasil PISA menunjukkan bahwa siswa Indonesia masih rendah dalam literasi membaca, literasi matematika dan literasi sains (Mansur, 2018). Pada PISA permasalah yang disajikan umumnya merupakan masalah yang kompleks, dalam bidang matematika terkategori sebagai pemecahan masalah (Dewantara, 2019)

Pemecahan masalah didefinisikan sebagai suatu usaha mencari jalan keluar dari suatu kesulitan (Nofrianto et al., 2017). Pemecahan masalah juga dapat didefinisikan sebagai kemampuan atau kesanggupan individu untuk mencari jalan keluar dari masalah atau kesulitan yang dihadapi (Rismen et al., 2020). Melalui pemecahan masalah siswa dapat membangun pengetahuan baru (Geni \& Hidayah, 2017), melatih memilih dan menggunakan berbagai strategi yang relevan (Lidinillah, 2008), serta terbiasa memonitor dan merefleksi masalah (Sitanggang, 2017).

Banyak hasil penelitian yang mengemukakan tentang masih rendahnya kemampuan siswa di Indonesia dalam pemecahan masalah (Nahdi, 2018). Salah satu penyebabnya adalah guru sangat jarang memberikan masalah yang menantang (Asdarina et al., 2019) dan bahkan ada yang hampir tidak pernah memberikan soal bertipe pemecahan masalah (Siswono et al., 2012), terutama masalah yang bentuknya lebih kompleks dan tidak terstruktur (Dixon \& Brown, 2012; Permatasari \& Margana, 2014). Padahal hampir semua masalah yang terkait dengan kehidupan sehari-hari umumnya tidak terstruktur, kompleks, beragam, serta menuntut siswa untuk menggunakan kemampuan lainnya dalam menyelesaikan masalah, misalnya siswa harus menggunakan kemampuan modeling dan kemampuan argumentatifnya (Kemendikbud, 2014). Hal inilah yang menjadi penyebab mengapa kebanyakan siswa tidak mampu menyelesaikan masalah-masalah yang kompleks, termasuk masalah yang disajikan dalam bentuk word problems.

Ada faktor lain yang menjadi penyebab kesulitan yang dihadapi siswa. Misalnya banyak siswa yang mengalami kesulitan dalam menyelesaikan masalah tipe word problems (Seifi et al., 2012). Diantaranya siswa kesulitan memahami dan merepresentasikan masalah, kesulitan merencanakan penyelesaian, dan kesulitan dalam melaksanakan penyelesaian (Hasan, 2015; Arifin et al., 2020). Dari aspek penyelesaian, dapat dilihat bahwa ada dua proses lain yang dilibatkan, yaitu: representasi dan eksekusi (Montague, 2012; Sajadi et al., 2013). Siswa yang mengalami kesulitan dalam menyelesaikannya sering kali disebabkan karena tidak bisa merepresentasikan masalah tersebut. Siswa cenderung bingung dan tidak tahu apa yang harus dituliskan. Siswa biasanya menemukan kesulitan dalam menerjemahkan representasi kata menjadi representasi matematika. Kesulitan tersebut dengan pemerolehan konsep image dan proses mentransformasikannya menjadi gambar dinamis, menggunakan gambar formula dari memori (Dostál, 2015).

Untuk menumbuhkan kemampuan pemecahan masalah siswa, terutama pada masalah tipe word problems yang tidak terstruktur dengan jelas, kompleks dan tidak beraturan dapat dilakukan melalui pembelajaran dikelas dengan beberapa intervensi dari guru mereka dan diberikan setiap hari (Karatas \& Baki, 2013). Salah satu bentuk intervensi kelas yang dapat meningkatkan hasil belajar matematika diantaranya ditekankan pada latihan menyelesaikan masalah dan merefleksi masalah tipe word problems setiap hari. Agar siswa dapat menyelesaikan masalah tipe word problems siswa harus diajarkan menggunakan skenario kehidupan nyata yang memberikan peluang kepada siswa untuk menjadi pemecah masalah kehidupan nyatanya sendiri (Bostic et al., 2016).

Penelitian sebelumnya memang sudah banyak yang meneliti tentang kemampuan pemecahan masalah, tetapi tidak belum ada yang menggunakan soal pemecahan masalah berbentuk word problems berkonteks wisata di Palembang. Selain itu dari penelitian terdahulu 
juga belum ditemukan analisis kemampuan pemecahan masalah yang ditinjau dari aspek memahami, merencanakan, dan menyelesaikan masalah serta faktor yang mempengaruhinya. Berdasarkan uraian di atas, peneliti bertujuan untuk menganalisis kemampuan pemecahan masalah siswa dalam menyelesaikan soal tipe word problems beserta faktor penyebabnya.

Penelitian ini juga diharapkan dapat memberikan manfaat bagi guru dalam merancang proses pembelajaran yang dapat meningkatkan kemampuan siswa di dalam memecahkan masalah matematika. Selain itu juga diharapkan dapat memberikan acuan bagi peneliti lain untuk mengembangkan, meningkatan, dan mengatasi permasalahan yang terkait dengan kemampuan pemecahan masalah siswa terkait permasalahan berbentuk word problems.

\section{Metode Penelitian}

Metode penelitian yang digunakan di dalam penelitian ini merupakan penelitian deskriptif. Adapun subjek penelitian ini adalah siswa-siswi kelas 9 di SMP Negeri 3 Palembang yang berjumlah 19 orang. Pemilihan subjek ini didasarkan pada kondisi yang dimiliki siswasiswi pada kelas 9 dimana umumnya mereka sudah memiliki pengetahuan tentang fakta dan konsep matematika yang sudah relatif banyak, serta memiliki penalaran yang cukup baik jika dibanding kelas 7 dan kelas 8 . Sehingga dengan pengetahuan dan kemampuan penalaran yang telah dimilikinya tersebut diharapkan mampu menyelesaikan soal-soal tipe pemecahan masalah.

Teknik pengumpulan data yang digunakan dalam penelitian ini terdiri dari teknik tes dan angket. Teknik tes digunakan untuk mengukur kemampuan siswa, sedangkan teknik angket untuk mengukur persepsi siswa. Kemampuan siswa dalam menyelesaikan soal pemecahan masalah diukur menggunakan soal tes pemecahan masalah. Ada 4 butir soal yang digunakan dalam mengukur kemampuan pemecahan masalah. Bentuk soal tes yang digunakan dalam penelitian ini adalah soal uraian berbentuk word problems yang memuat konteks wisata di Palembang diantaranya tentang wisata Pulau Kemaro, Jembatan Ampera, Monpera dan Kambang Iwak. Soal yang diberikan juga sudah sesuai dengan karakteristik soal pemecahan masalah dan telah memenuhi kriteria valid.

Adapun permasalahan yang diberikan adalah sebagai berikut:

Masalah 1: Atap pagoda berbentuk segi delapan yang bertumpuk. Jika diameter pagoda lantai terbawah (di tanah) adalah $13 \mathrm{~m}$, dan diameter setiap lantai memiliki selisih $50 \mathrm{~cm}$. Prediksilah luas atap pagoda jika atap pagoda berada di atas lantai 9? Jelaskan strategi yang anda gunakan!

Masalah 2: Monpera terdiri dari delapan lantai. Lima lantai bawah diisi dan dijadikan musium. Di ruangan museum terdapat berbagai koleksi yang menjadi saksi bisu perang lima hari lima malam di Palembang. Pada lantai pertama terdapat koleksi senjata. Dilantai 2 terdapat berbagai dokumen dan foto masa itu. Di lantai 3 terdapat koleksi uang lama. Di lantai 4 dan 5 terdapat patung dan baju dari para pahlawan. Jika petugas Monpera ingin menata ulang kembali semua koleksi yang ada dengan syarat bahwa koleksi tidak diletakkan dilantai yang sama, maka tentukan berapa cara yang mungkin untuk menata koleksi-koleksi tersebut?

Masalah 3. Kambang iwak dikelilingi oleh jogging track yang berukuran $500 \mathrm{~m}$ dan lebar 4 $m$. Jogging track dipinggiran kambang iwak berfungsi sebagai jalur pedestrian, akan tetapi sering kali dimanfaatkan sebagai jalur bersepeda, dan aktivitas olahraga lainnya. Suatu pagi Aisyah dan Fachry sedang melakukan aktivitas olahraga bersama. Aisyah melakukan aktivitas jogging dan rata-rata kecepatan larinya adalah 125 m setiap menit, dan Fachry berkeliling kambang iwak menaiki sepedanya dengan kecepatan rata-rata $375 \mathrm{~m}$ per menit. Tentukan berapa kali Fachry dan Aisyah akan berpapasan dalam dua jam, jika Fachry dan Aisyah melakukan aktivitas berlawanan arah?

Masalah 4. Jika kedua jarum jam di Jembatan Ampera diputar 3600 maka akan terbentuk dua buah lingkaran seperti pada gambar di atas. Diketahui perbandingan antara jarum pendek dan jarum panjang adalah 1:2. 
JURNAL GANTANG. Maret 2021; VI(1): 29 - 38

p-ISSN. 2503-0671

e-ISSN. 2548-5547

Jika bagian jam akan dicat (sepertis gambar di atas), maka estimasilah luas daerah yang dicat tersebut tersebut?

Pada penelitian ini angket digunakan untuk mengumpulkan persepsi siswa terhadap pemecahan masalah. Angket persepsi terbagi menjadi dua aspek yaitu pemahaman dan keyakinan. Angket yang digunakan berbentuk angket terbuka. Siswa diberikan kebebasan untuk memberikan jawaban dalam bentuk kalimat panjang atau kalimat pendek.

Data yang diperoleh berupa data kualitatif dan data kuantitatif. Oleh karena itu, data yang telah dikumpulkan juga dianalisis secara kualitatif dan kuantitatif. Data hasil tes yang diperoleh dari jawaban siswa dikelompokkan dalam tiga aspek yaitu aspek kemampuan mengungkap informasi dan masalah, aspek merencanakan penyelesaian masalah, dan aspek penyelesaian masalah. Dari jawaban siswa ini selanjutnya dilihat apakah siswa menuliskan ketiga aspek tersebut dan apakah aspek yang dituliskannya benar atau tidak. Agar lebih mudah dibaca dan dipahami maka data dari ketiga aspek tersebut disajikan dalam bentuk diagram batang. Data yang diperoleh dari angket persepsi dianalisis secara dianalisis secara deskriptif. Selanjutnya data yang terkumpul dihitung persentase setiap aspeknya dan disajikan dalam bentuk diagram serta disajikan dalam bentuk narasi.

Untuk mengetahui tentang proses dan strategi serta solusi dalam penyelesaian masalah, maka semuanya dapat tergambar dari penggunaan notasi dan istilah serta representasi matematis yang sesuai yang terdapat pada lembar jawaban siswa, serta tergambar bahwa penyelesaian yang diberikan telah dituliskan secara runtut, koheren, dan sistematis. Kemampuan pemecahan masalah dipengaruhi oleh: (1) penguasaan fakta dan konsep yang sesuai dengan masalah yang dan berhubungan dengan pemahaman masalah; (2) penguasaan prosedur dan pemilihan strategi yang sesuai dengan masalah; (3) penguasaan prosedur operasi matematis untuk mencari penyelesaian masalah. Kemampuan pemecahan masalah dapat diketahui dari apakah siswa mengetahui informasi dan konsep matematis yang sesuai dan yang diperlukan untuk menyelesaikan masalah serta dapat memeriksa kesesuaian atau kebenaran solusi. Adapun indikator yang digunakan untuk mengamati kemampuan siswa dalam pemecahan masalah adalah sebagai berikut:

Tabel 1

Indikator dalam pemecahan masalah

\begin{tabular}{|c|c|c|}
\hline Aspek & & Indikator \\
\hline Pemahaman & 1) & $\begin{array}{l}\text { Mampu menggunakan } \\
\text { terminologi dan notasi yang } \\
\text { sesuai, } \\
\text { Mampu mengidentifikasi fakta, } \\
\text { data, atau informasi yang } \\
\text { dibutuhkan dalam penyelesaian } \\
\text { masalah, } \\
\text { Mampu membuat dan } \\
\text { menyajikan model matematis } \\
\text { dari masalah tersebut. }\end{array}$ \\
\hline $\begin{array}{l}\text { Perencanaan } \\
\text { Solusi }\end{array}$ & 1) & $\begin{array}{l}\text { Mampu memahami konsep dan } \\
\text { prinsip matematis terkait } \\
\text { masalah yang diselesaikan, } \\
\text { Mampu memahami keterkaitan } \\
\text { antar elemen-elemen tersebut, } \\
\text { Mampu menggunaan strategi } \\
\text { yang efisien dan mengarah pada } \\
\text { solusi masalah. }\end{array}$ \\
\hline $\begin{array}{l}\text { Pelaksanaan } \\
\text { Solusi }\end{array}$ & 1) & $\begin{array}{l}\text { Mampu menggunakan } \\
\text { algoritma secara lengkap dan } \\
\text { benar, } \\
\text { Mampu menggunaan strategi } \\
\text { penyelesaian masalah yang } \\
\text { sistematis, } \\
\text { Mampu menunjukkan } \\
\text { penalaran yang logis dan tajam, } \\
\text { Mampu melakukan prosedur } \\
\text { matematis yang akurat, } \\
\text { Mampu menggunakan } \\
\text { representasi matematis secara } \\
\text { tepat. }\end{array}$ \\
\hline
\end{tabular}

\section{Hasil dan Pembahasan}

Dari lembar jawaban siswa selanjutnya dilihat apakah siswa menuliskan aspek yang menjadi fokus dalam penelitian ini seperti menuliskan informasi dan masalah, menuliskan perencanaan, dan menuliskan penyelesaian. Kemudian dilihat kembali apakah informasi dan masalah yang dituliskan benar atau tidak, perencanaan yang dilakukan benar atau tidak dan penyelesaian yang dibuat juga benar atau tidak. Data hasil analisis tes pemecahan masalah disajikan pada Gambar 1. 


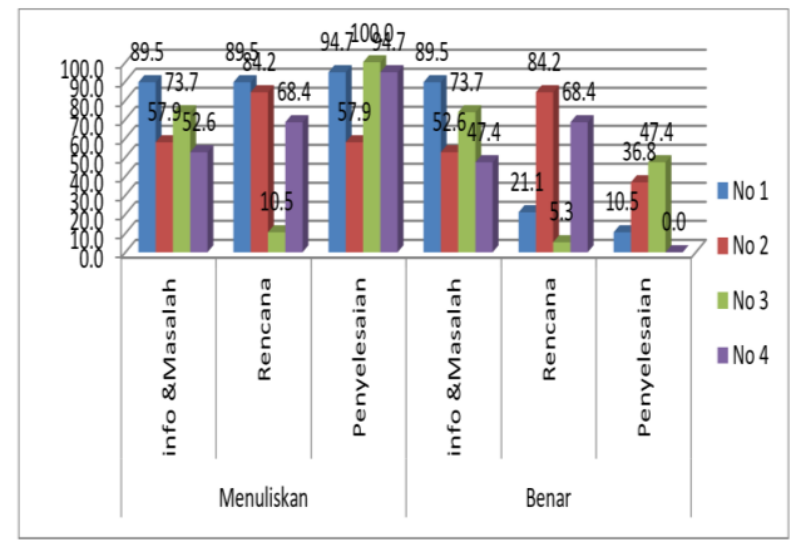

Gambar 1. Hasil tes pemecahan masalah

Dari Gambar 1 di atas terlihat bahwa mayoritas siswa menuliskan informasi dan masalah untuk masalah 1. Mayoritas siswa menuliskan rencana juga untuk masalah 1 , dan mayoritas siswa menuliskan penyelesaian untuk masalah 3. Dari data di atas terlihat bahwa semua siswa menuliskan jawaban untuk masalah 3. Dari data juga terlihat bahwa ada siswa yang tidak menuliskan informasi dan masalah serta tidak melakukan perencanaan tetapi menuliskan penyelesaian.

Pada masalah 1, siswa sudah mampu menuliskan informasi yang ada pada masalah, tetapi mengalami kesulitan dalam melakukan penyelesaian masalah, dikarenakan kurangnya pengetahuan terkait konsep apa yang akan digunakan di dalam menyelesaikan masalah. Sedangkan pada masalah nomor 3, kebanyakan siswa dapat menyelesaikan masalah nomor 3 dengan tepat, dikarenakan pada soal nomor 3 siswa sudah dapat mengidentifikasi masalah dan dapat menuliskan informasi dengan benar, kemudian siswa juga dapat membuat perencanaan karena memiliki konsep yang baik tentang permasalahan. Sehingga pada proses penyelesaian siswa tidak mengalamai kesulitan.

Dari data di atas terlihat bahwa mayoritas siswa benar dalam menuliskan informasi dan masalah 1. Mayoritas siswa benar dalam menuliskan rencana untuk masalah 2 . Mayoritas siswa benar menuliskan penyelesaian untuk masalah 3. Dari data di atas terlihat juga bahwa meskipun siswa sudah menuliskan informasi dan masalah dengan benar tetapi tidak menjamin bahwa mereka pasti akan membuat penyelesaian dengan benar pula. Dari hasil analisis jawaban siswa diperoleh bahwa siswa sudah mampu menuliskan informasi yang terdapat pada masalah, akan tetapi informasi yang dituliskan masih kurang lengkap. Situasi tersebut lazim ditemukan dalam penelitian sebelumnya, siswa sering kali tidak tahu informasi penting (Akbar et al., 2017), siswa tidak tahu apakah informasi yang terdapat dalam masalah sudah cukup atau belum (Utami \& Wutsqa, 2017), selain itu siswa yang tahu semua kata dalam masalah tidak lantas dapat mengubahnya dalam notasi atau model matematis (White, 2005) dan siswa kurang mampu memadukan semua informasi menjadi satu dalam domain matematika (Geary, 2004).

Dari data di atas terlihat bahwa mayoritas siswa benar dalam menuliskan informasi dan masalah yang terdapat pada masalah 1 dan 3. Siswa cenderung mengalami kesulitan dalam menuliskan informasi dan masalah 2 dan 4 . Hal ini dikarenakan pada soal 1 dan 3 informasi yang diketahui dan masalah yang ingin diselesaikan telah tersurat dengan dengan jelas, akan tetapi pada masalah 2 dan 4 informasi yang diketahui dan masalah yang ingin diselesaikan masih tersirat dalam bahasa lain pada masalah. Berikut ini contoh informasi yang dituliskan siswa pada dalam menyelesaikan masalah 2 dan 4.

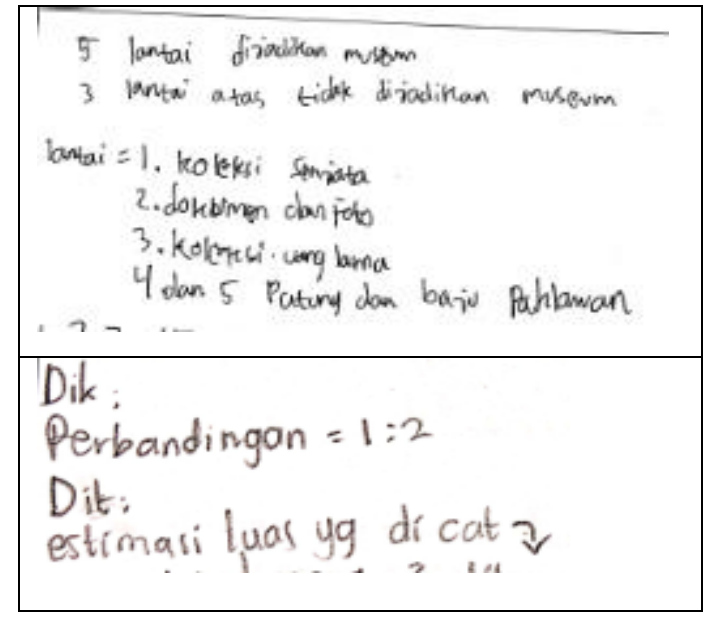

Gambar 2. Menuliskan informasi diketahui

Dari Gambar 2 di atas, terlihat bahwa meskipun informasi yang diketahui tersirat di 


\section{JURNAL GANTANG. Maret 2021; VI(1): 29 - 38 \\ p-ISSN. 2503-0671 \\ e-ISSN. 2548-5547}

dalam masalah, tetapi ada beberapa siswa yang mampu mengungkapkannya. Dalam hal ini, siswa sudah mampu mengidentifikasi data atau informasi yang diperlukan untuk menyelesaikan masalah, tetapi masih belum mampu menggunakan terminologi dan notasi yang sesuai, serta belum mampu mengubah masalah tersebut dalam model matematis. Siswa-siswa cenderung menggunakan bahasa sendiri dan dalam bentuk matematika informal ketika menuliskan informasi yang ada pada masalah karena dianggap lebih mudah. Akan tetapi, informasi yang dituliskan terkadang masih terkategori belum lengkap dan belum sempurna (Dahlan \& Juandi, 2011).

Dari data pada Gambar 1 di atas terlihat bahwa mayoritas siswa menuliskan rencana untuk menyelesaikan masalah 1 , akan tetapi perencanaan yang dibuat salah dan tidak mengarah pada penyelesaian. Siswa-siswa yang menuliskan rencana untuk masalah 2 dan 4, mereka telah membuat perencanaan yang benar. Dari data di atas terlihat bahwa mayoritas siswa tidak menuliskan rencana untuk masalah 3 . Berikut ini contoh jawaban siswa pada masalah 3.

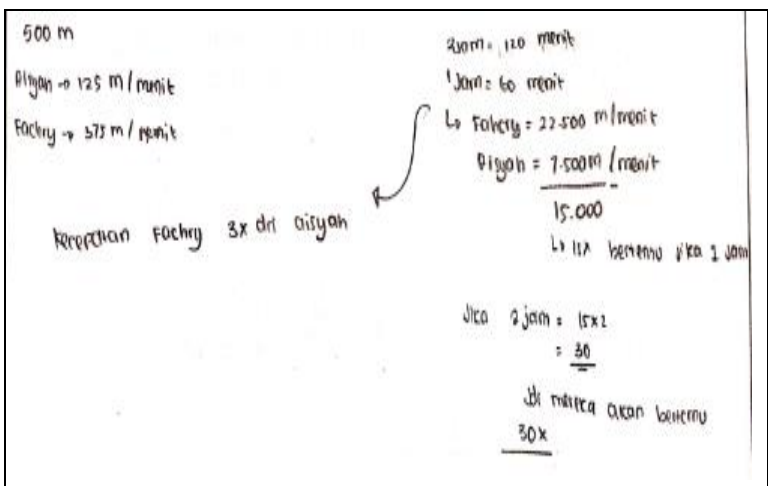

Gambar 3. Tidak menuliskan perencanaan

Dari Gambar 3 di atas terlihat bahwa siswa tersebut tidak menuliskan perencanaan dalam menyelesaikan masalah. Perencanaan dalam penyelesaia masalah merupakan jembatan bagi siswa untuk mempermudah proses penyelesaian masalah menggunakan informasi yang telah tersedia.

Dari jawaban siswa di atas, diperoleh informasi bahwa siswa sudah memahami konsep dan prinsip matematis terkait masalah yang diselesaikan, akan tetapi kurang mampu dalam memahami keterkaitan antar elemen-elemen tersebut, sehingga tidak dapat menentukan strategi yang efisien dan mengarah pada solusi masalah. Secara umum dapat dikatakan bahwa siswa tidak cukup hanya mengetahui informasi yang termuat pada masalah (Herman Tatang, 2007), meraka perlu keterampilan mengkoneksikan informasi ini dengan pengetahuan sebelumnya terutama konsep atau prosedur yang dinilai relevan untuk menyelesaikan masalah ini (Mawaddah \& Maryanti, 2016).

Dari data pada Gambar 1. di atas terlihat bahwa hampir semua siswa menuliskan penyelesaian untuk masalah 1 , 3, dan 4, akan tetapi mayoritas dari mereka memberikan penyelesaian yang salah. Terkadang penyelesaian yang diberikan belum selesai. Dari data tersebut mayoritas siswa memberikan penyelesaian yang benar untuk masalah 1 .

Kesalahan dalam menyelesaikan masalah 1, mayoritas siswa terkecoh dengan kata diameter yang ada pada masalah. Siswa yang salah dalam menginterpretasi makna kata diameter umumnya langsung mengaitkan dengan konsep luas lingkaran untuk menyelesaikan masalah ini. Padahal pada masalah jelas tertulis bahwa yang ditanyakan adalah luas segidelapan. Dari jawaban siswa di atas terlihat bahwa siswa tersebut paham dengan kata diameter yang mewalikili diameter lingkaran luar dari sebuah segidelapan, dan ia juga tahu bahwa segidelapan dapat terbentuk dari delapan buah segitiga.

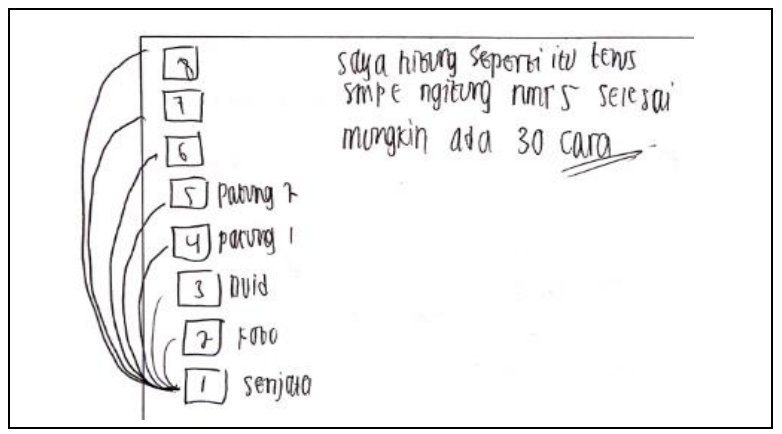

Gambar 4. Tahu informasi dan dapat merencanakan 
Dari jawaban siswa pada Gambar 4, siswa mampu mengidentifikasi data atau informasi yang diperlukan untuk menyelesaikan masalah, tetapi masih belum mampu menggunakan terminologi dan notasi yang sesuai, serta belum mampu mengubah masalah dalam bentuk model matematis. Siswa tersebut juga mampu memahami konsep dan prinsip matematis terkait masalah yang diselesaikan, mampu memahami keterkaitan antar elemenelemen tersebut, serta mampu menggunaan strategi yang efisien dan mengarah pada solusi masalah. Hal ini relevan dengan temuan pada penelitian sebelumnya yang mengemukakan bahwa siswa yang mampu memahami apa yang diinginkan soal, tetapi sulit menganalisis fakta yang ada pada soal (Utami \& Wutsqa, 2017), juga akan mengalami kesulitan dalam hal mengidentifikasi pola dan operasi yang dibutuhkan untuk menyelesaikan soal tersebut (Sari dan Wijaya, 2017).

Pada Gambar 4 terlihat bahwa siswa tahu informasi yang tersedia dan masalah yang ingin diselesaikan serta telah merencanakan dengan baik. Akan tetapi siswa kurang teliti dan lupa jika yang akan disusun ulang hanya lantai 1 sampai lantai 5. Hal ini sejalan dengan penelitian sebelumnya yang mengemukakan bahwa sangat mungkin siswa yang mampu mengidentifikasi operasi dan pola soal tetapi gagal dalam membuat penyelesaian dan kesimpulan (White, 2005).

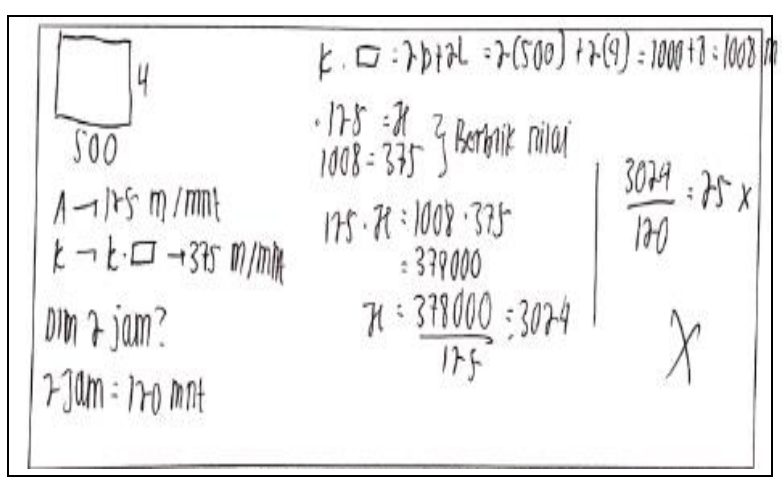

Gambar 5. Jawaban salah

Hal yang hampir sama juga terlihat dari jawaban siswa di atas. Pada Gambar 5 di atas terlihat bahwa siswa sudah melakukan kesalahan mulai dari mengidentifikasi unsur yang diketahui pada masalah. Siswa menuliskan bahwa jogging track berbentuk persegi panjang. Hal ini mengakibatkan siswa melakukan kesalahan dalam membuat perencanaan. Padahal pada masalah tidak dijelaskan bahwa jogging track berbentuk persegi panjang. Hal ini menjadi salah satu penyebab mengapa siswa melakukan kesalahan dalam membuat penyelesaian.

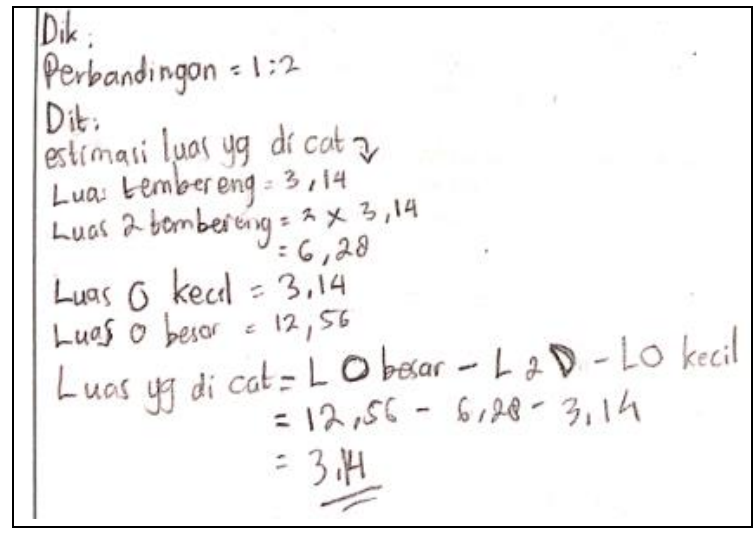

Gambar 6. Penyelesaian salah

Pada Gambar 6 terlihat bahwa siswa tidak dapat mengingat konsep tentang tembereng pada lingkaran yang mengakibatkan terjadinya kesalahan di dalam perhitungan luas tembereng. Meskipun siswa sudah mampu mengidentifikasi informasi yang diketahui, dan mampu mengidentifikasi masalah yang akan diselesaikan, serta mampu membuat perencanaan, tetapi salah dalam membuat penyelesaian. Terlihat bahwa siswa sudah mampu menggunakan algoritma secara lengkap dan benar, dan dapat menggunaan strategi penyelesaian masalah yang sistematis, serta penalaran yang logis dan tajam. Akan tetapi salah di dalam melakukan prosedur matematis yang akurat. Hal ini sejalan dengan peneliian sebelumnya yang mengemukakan bahwa terkadang Sebagian besar siswa bingung Ketika membuat keterkaitan dan hubungan antara informasi yang diketahui dan perencanaan, sehingga siswa sering salah dalam menyelesaikan soal (Utami \& Wutsqa, 2017).

Setelah dilakukan tes pemecahan 
JURNAL GANTANG. Maret 2021; VI(1): 29 - 38

p-ISSN. 2503-0671

e-ISSN. 2548-5547

masalah, selanjutnya diberikan angket untuk mengetahui persepsi siswa terhadap masalah yang diberikan. Angket persepsi yang diberikan kepada siswa terbagi menjadi dua aspek yaitu tentang pemahaman dan keyakinan yang dimiliki siswa terhadap masalah.

Untuk angket persepsi dengan aspek pemahaman memiliki delapan komponen yang terdiri dari unsur-unsur berikut: kata, kalimat, lingkup, masalah, pengungkapan dalam bahasa sendiri, kecukupan informasi, adanya informasi lain dalam masalah, dan prediksi kemungkinan dapat diselesaikan. Berikut ini hasil angket persepsi untuk aspek pemahaman siswa.

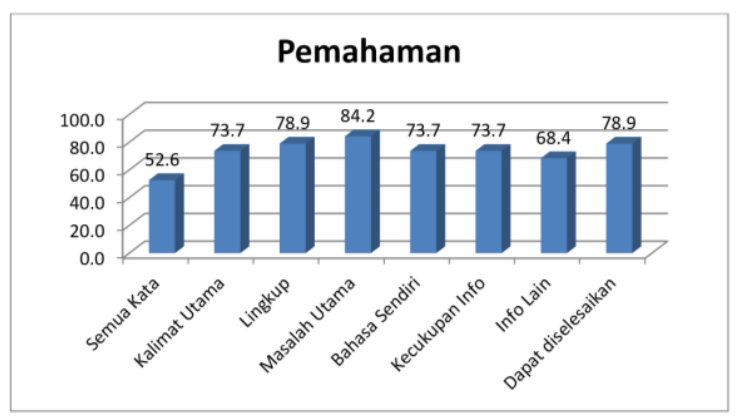

Gambar 7. Hasil angket persepsi aspek pemahaman

Dari data pada Gambar 7 terlihat bahwa mayoritas siswa tahu lingkup materi, kalimat utama, masalah utama, serta dapat menceritakan dalam bahasa sendiri. Dari data di atas terlihat juga bahwa hanya 52,6 \% siswa yang memahami semua kata yang terdapat pada masalah. Berdasarkan hasil wawancara diperoleh infomasi bahwa masih ada kata yang tidak mereka pahami, misalnya kata "prediksi" pada masalah 1 dan kata "estimasi" pada masalah 4. Bagi mereka penggunaan kata ini seolah-olah tidak menuntut jawaban yang real melainkan jawaban yang sifatnya hanya hampiran saja.

Dari Gambar 6 di atas terlihat bahwa $68,4 \%$ siswa tahu bahwa perlu informasi lain untuk menyelesaikan masalah diatas. Akan tetapi sebagian tidak dapat menggunakan pengetahuan sebelumnya yang pernah mereka miliki untuk menyelesaikan masalah ini. Dari data diatas menunjukkan bahwa kemampuan pemecahan masalah yang dimiliki siswa tidak dipengaruhi 


\section{Kesimpulan}

Berdasarkan hasil tes dapat disimpullkan bahwa dalam menyelesaikan soal pemecahan masalah mayoritas siswa telah memahami masalah. Akan tetapi hanya sebagian kecil siswa yang dapat menyelesaikan masalah dengan benar. Banyak siswa yang tidak membuat perencanaan dalam menyelesaikan masalah padahal perencanaan dapat digunakan sebagai jembatan dalam penggunaan informasi dan pengetahuan yang telah mereka miliki sebelumnya untuk menyelesaikan masalah. Sedangkan dari hasil angket maka dapat dismpulkan bahwa ada beberapa faktor penting yang mempengaruhi keberhasilan siswa dalam menyelesaikan masalah, diantaranya aspek suka atau tidak pada matematika, tidak ingat dengan konsep dan teorema yang dapat digunakan untuk menyelesaikan masalah frekuensi seberapa sering latihan matematika, atau pengalaman masa lalu seperti merasa pernah menyelesaikan masalah yang mirip.

Dalam penelitian ini perlu untuk lebih digali lagi penyebab dari sulitnya siswa dalam memahami, merencanakan dan menyelesaikan masalah dengan menggunakan instrument lain yang relevan. Dan perlu dikaji lagi tentang hubungan antara kemampuan pemecahan masalah dengan kemampua matematis lainnya. Dari hasil penelitian ini juga dapat disarankan bagi guru agar membiasakan siswa di dalam pembelajaran dengan memberikan soal-soal pemecahan masalah yang memuat konteks kehidupan sehari-hari. Kemudian guru melatih dan membiasakan siswa untuk memahami masalah, membuat perencanaan dalam menyelesaikan masalah, dan menyelesaikan permasalahan dengan cara yang lebih kreatif.

\section{Ucapan Terimakasih}

Penulis mengucapkan terima kasih kepada Kepala Sekolah, Wakil Kepala Sekolah, Guru Matematika SMP Negeri 3 Palembang yang telah memberikan izin untuk mengambil data penelitian serta kepada siswa-siswi SMP Negeri 3 Palembang yang telah bersedia menjadi responden pada penelitian ini.

\section{Referensi}

Akbar, P., Hamid, A., Bernard, M., \& Sugandi, A. I. (2017). Analisis kemampuan pemecahan masalah dan disposisi matematik siswa kelas XI SMA Putra Juang dalam materi peluang. Jurnal Cendekia: Jurnal Pendidikan Matematika, 2(1), 144-153. https://doi.org/10.31004/cendekia.v2i1.62

Arifin, S., Zulkardi, Putri, R. I. I., Hartono, Y., \& Susant, E. (2020). Scaffolding in mathematical problem-solving. Journal of Physics: Conference Series, 1480(1), 0-8. https://doi.org/10.1088/17426596/1480/1/012054

Asdarina, O., Rahmah, J., \& Hajidin. (2019). Upaya guru mengembangkan karakter berpikir kritis dan berpikir kreatif siswa melalui pembelajaran matematika. Jurnal Peluang. 7(1), 31-43.

Bostic, J., Pape, S., \& Jacobbe, T. (2016). Encouraging sixth-grade students' problem-solving performance by teaching through problem solving. In Investigations in Mathematics Learning, 8(3). The Research Council on Mathematics Learning https://doi.org/10.1080/24727466.2016.117 90353

Dahlan, J. A., \& Juandi, D. (2011). Analisis representasi matematik siswa sekolah dasar dalam penyelesaian masalah matematika kontekstual. Jurnal Pengajaran Matematika dan Ilmu Pengetahuan Alam, 16(1), 128. https://doi.org/10.18269/jpmipa.v16i1.273

Dewantara, A. H. (2019). Soal matematika model PISA: Alternatif materi program pengayaan. DIDAKTIKA: Jurnal Kependidikan, 12(2), 197-213. https://doi.org/10.30863/didaktika.v12i2.18 6

Dixon, R., \& Brown, R. (2012). Transfer of learning: Connecting concepts during problem solving. Journal of Technology Education, 24(1), 2-17. https://doi.org/10.21061/jte.v24i1.a.1

Dostál, J. (2015). Theory of problem solving. Procedia - Social and Behavioral Sciences, 174,2798-2805. https://doi.org/10.1016/j.sbspro.2015.01.97 
JURNAL GANTANG. Maret 2021; VI(1): 29 - 38

p-ISSN. 2503-0671

e-ISSN. 2548-5547

0

Geni, P. R. L., \& Hidayah, I. (2017). Kemampuan pemecahan masalah siswa pada pembelajaran problem based learning bernuansa etnomatematika ditinjau dari gaya kognitif. Unnes Journal of Mathematics Education Research, 6(1), $11-17$.

Geary, D. C. (2004). Mathematics and learning disabilities. Journal of learning disabilities, 37(1), 4-15.

Hasan, B. (2015). Penggunaan scaffolding untuk mengatasi kesulitan menyelesaikan masalah matematika. APOTEMA: Jurnal Program Studi Pendidikan Matematika, 1(1), 88-98. https://doi.org/10.31597/ja.v1i1.169

Herman Tatang. (2007). Pembelajaran berbasis masalah untuk meningkatkan kemampuan berpikir matematis tingkat tinggi siswa SMP. Educationist, l(1), 3. http://ejournal.sps.upi.edu/index.php/educat ionist/article/view/28/22

Karatas, I., \& Baki, A. (2013). The effect of learning environments based on problem solving on students' achievements of problem solving. International Electronic Journal of Elementary Education, 5(3), 249-267.

Lidinillah, D. A. M. (2008). Strategi pembelajaran pemecahan masalah di sekolah dasar. Jurnal Pendidikan Dasar, $1-10$.

Mansur, N. (2018). Melatih literasi matematika siswa dengan soal PISA. Prisma, 1, 140144.

https://journal.unnes.ac.id/sju/index.php/pri sma/\%0AMelatih

Mawaddah, S., \& Maryanti, R. (2016). Kemampuan pemahaman konsep matematis siswa smp dalam pembelajaran menggunakan model penemuan terbimbing (discovery learning). EDU-MAT: Jurnal Pendidikan Matematika, 4(1), 76-85. https://doi.org/10.20527/edumat.v4i1.2292

Montague, M. (2012). Math problem solving for middle school students with disabilities. 113.

Nahdi, D. S. (2018). Eksperimentasi model problem based learning dan model guided discovery learning terhadap kemampuan pemecahan masalah matematis ditinjau dari self efficacy siswa. Jurnal Cakrawala Pendas, https://doi.org/10.31949/jcp.v4i1.711

Nofrianto, A., Susanti, W., \& Amri, M. (2017). Peningkatan kemampuan pemecahan masalah matematika siswa melalui model pembelajaran laps-heuristic dikelas $\mathrm{X}$ SMAN 2 Batang Anai. Jurnal Gantang, 1(2), 39-50. https://doi.org/10.31629/jg.v1i2.52

Permatasari, N., \& Margana, A. (2014). Meningkatkan kemampuan siswa dalam memecahkan masalah matematika dengan model pembelajaran treffinger. Mosharafa: Jurnal Pendidikan Matematika, 3(1), 3142.

Rismen, S., Juwita, R., \& Devinda, U. (2020). Analisis kemampuan pemecahan masalah matematika siswa ditinjau dari gaya kognitif impulsif. Jurnal Gantang, 5(1), 61-68. https://doi.org/10.31629/jg.v5i1.1579

Sajadi, M., Amiripour, P., \& RostamyMalkhalifeh, M. (2013). The examinig mathematical word problems solving ability under efficient representation aspect. Mathematics Education Trends and Research, 2013, 1-11. https://doi.org/10.5899/2013/metr-00007

Seifi, M., Haghverdi, M., \& Azizmohamadi, F. (2012). Recognition of students' difficulties in solving mathematical word problems from the viewpoint of teachers. Journal of Basic and Applied Scientific Research, 2(3).

Siswono, T., Rosyidi, A., Astuti, Y., \& Kurniasari, I. (2012). Pemberdayaan guru dalam pembelajaran matematika untuk meningkatkan kemampuan berpikir kreatif siswa SD. Jurnal Ilmu Pendidikan, 2, 211.

Utami, R. W., \& Wutsqa, D. U. (2017). Analisis kemampuan pemecahan masalah matematika dan self-efficacy siswa SMP negeri di Kabupaten Ciamis. Jurnal Riset Pendidikan Matematika, 4(2), 166-175.

White, A. L. (2005). Active mathematics in classrooms: Finding out why children make mistakes-and then doing something to help them. Square one, 15(4), 15-19. 